\title{
Evaluating the ecological relevance of habitat maps for wild herbivores
}

\author{
MARC E. STALMANS, ED T.F. WITKOWSKI, AND KEVIN BALKWILL
}

Authors are respectively Ecologist, Head of the Restoration and Conservation Biology Research Group and Curator of the C.E. Moss Herbarium, Department of Animal, Plant and Environmental Sciences, University of the Witwatersrand, Private Bag 3, Wits 2050, Republic of South Africa. Present address of the first author is Mpumalanga Parks Board, PO Box 1990, 1200 Nelspruit, Republic of South Africa.

\begin{abstract}
Informed management of large herbivores depends largely on how well habitat availability and suitability are understood. The aims of the study were to quantify and map the distribution of sour and mixed grasslands in the 48,000 ha Songimvelo Game Reserve, Mpumalanga, South Africa. Mixed grassland retains its forage quality and hence its ability to sustain animal production for longer in the year than sour grassland. An unsupervised classification technique was applied to a LANDSAT 5 TM image acquired in 1993. The probability that each resulting cluster represented either sour or mixed grassland was calculated based on the proportional allocation of 428 sample plots. The 2 resulting probability maps were combined into a single image by selecting the class image that contained the maximum posterior probability and assigning that class to the output pixel. The accuracy of the vegetation map was assessed by ground-truthing with an independent set of 85 plots. This yielded a correct classification of $84.8 \%$ for the sour and $76.9 \%$ for the mixed plots. The mixed grasslands covered only $31.0 \%$ of the area but accounted for $66.1 \%$ of the game stocking. Water is widely distributed and is not a limiting factor to habitat selection. Based on a GIS analysis, the qualitative difference between mixed and sour grasslands overrides quantitative differences in forage availability, fire history and human disturbance in influencing herbivore distribution. The integration of field data and satellite imagery into a GIS system thus offers a powerful tool for the objective quantification and mapping of available habitat.
\end{abstract}

Key Words: wildlife, GIS, remote sensing, LANDSAT, groundtruthing

The informed management of large herbivores in conservation areas depends largely on how well habitat availability and suitability are understood. The Songimvelo Game Reserve (henceforth SGR) is spatially very diverse in terms of its average annual rainfall, underlying geological substrate, elevation, slope, and aspect (Barnes 1998). This results in a very diverse vegetation pattern with marked differences in habitat suitability for herbi-

Funding and logistical support were provided by the Mpumalanga Parks Board. Authors wish to acknowledge the support by Wilna Heymans who collected the independent data set used for the validation of the satellite map. Magda Rall, Annelize Steyn and other management staff assisted with the collection of vegetation, fire and game monitoring data. Dr Y. Bai and 2 anonymous reviewers provided useful comments and recommendations.

Manuscript accepted 12 Apr. 2001

\section{Resumen}

El manejo actualizado de los grandes herbívoros depende en gran parte de que tan bien son entendidos la disponibilidad y lo apropiado del hábitat. Los objetivos de este estudio fueron cuantificar y mapear la distribución de los pastizales mixtos y ásperos en las 48,000 ha de la reserva de fauna Songimvelo en Mpumalanga, South Africa. Los pastizales mixtos conservan su calidad, y de aquí su habilidad para mantener la producción animal durante un mayor periodo de tiempo durante el año que los pastizales ásperos. Una técnica de clasificación no supervisada se aplicó a una imagen LANDSAT 5 TM adquirida en 1993. La probabilidad de que cada conglomerado resultante represente el pastizal mixto o el áspero se calculó en base a la asignación proporcional de 428 parcelas de muestra. Los 2 mapas de probabilidades resultantes se combinaron en una sola imagen seleccionando la clase de imagen que contenía la probabilidad máxima posterior $y$ asignando esa clase a la salida de pixel. La certeza del mapa de vegetación se evaluó mediante un reconocimiento terrestre con un juego independiente de 85 parcelas. Esto produjo una clasificación correcta en $\mathbf{8 4 . 4 \%}$ de las parcelas de pastizal ásperos y en $76.9 \%$ de las parcelas de pastizal mixto. El pastizal mixto cubría solo el $31 \%$ del área, pero sostenía el $66.1 \%$ de la carga animal de fauna. El agua esta ampliamente distribuida y no es un factor limitante en la selección del hábitat. Basado en un análisis de Sistemas de Información geográfica (GIS) las diferencias cualitativas entre los pastizales mixtos y los ásperos anulan las diferencias cuantitativas en la disponibilidad de forraje, la historia de fuego y el disturbio humano en influenciar la distribución de los herbívoros. La integración de datos de campo e imagen de satélite en un sistema de GIS ofrece una herramienta poderosa para el objetivo de cuantificación y mapeo del hábitat disponible.

vores (Stalmans et al. 1999). This diverse vegetation can be generalised into 2 herbivore habitats, 'sourveld' and 'mixed veld' (Stalmans et al. 1999) based on forage quality characteristics.

Within the South African ecological context, 'sourveld' refers to range in which the forage plants become unacceptable and less nutritious to large herbivores on reaching maturity. Sourveld consequently is utilised only during spring and summer (Trollope et al. 1990). 'Sweetveld' in contrast retains its acceptability and nutritive value after maturity and is used throughout most of the year. In essence, herbivores feeding on sourveld lose body weight during the dry winter season due to a decline in forage quality below the level for efficient digestion, whereas in sweetveld, for- 
age quality never declines such that animals cannot maintain growth (Ellery et al. 1995). 'Mixed veld' is intermediate between sourveld and sweetveld. Prior to this study, little quantitative information existed on the spatial extent and distribution of sour and mixed range across the reserve. This quantification is necessary in order to determine appropriate stocking levels of game. The range of game species present, their numbers and their distribution determine the potential for tourism development which is required in the face of the great socio-economic needs experienced by rural communities bordering the SGR (Heinsohn et al. 1992).

Remote sensing is a useful tool for inventory and evaluation of wildlife habitat because of its multispectral and multitemporal capabilities at different spatial scales (Quattrochi and Pelletier 1991). Processed remotely sensed data may be used as input to a Geographic Information System (GIS) and together with ancillary data be used for environmental modelling and analysis (Wilkinson 1996). Wildlife habitat maps derived from remote sensing need to be evaluated for accuracy and ecological relevancy before they are used for management purposes. Accuracy assessment relies on independent reference data, not used during the process of classification (Fairbanks and Thompson 1996).

The aim of the study was to evaluate the ecological relevance of habitat maps derived from multispectral remote sensing by first comparing the spatial distribution of the spectrally-derived habitats to the distribution obtained through field sampling and by secondly evaluating the actual herbivore distribution in relation to the spectrally-identified habitats.

\section{Materials and Methods}

\section{Study Area}

The Songimvelo Game Reserve (SGR) is located in the southeastern part of Mpumalanga on the South AfricanSwaziland border $\left(25^{\circ} 45^{\prime}\right.$ to $26^{\circ} 06^{\prime} \mathrm{S}$ and $30^{\circ} 46^{\prime}$ to $31^{\circ} 16^{\prime} \mathrm{E}$ ) and is approximately 48,000 ha in extent (Fig. 1). The terrain is generally rugged with elevation ranging from $600 \mathrm{~m}$ above sea level along the Komati River in the south to over $1,900 \mathrm{~m}$ in the north and northeast. The geology is very diverse and ranges from alluvium and mafic and ultramafic lavas in the Komati Valley, to felsic lavas, conglomerates, shales, sandstones and quartzites at higher elevations.

Rainfall is concentrated between

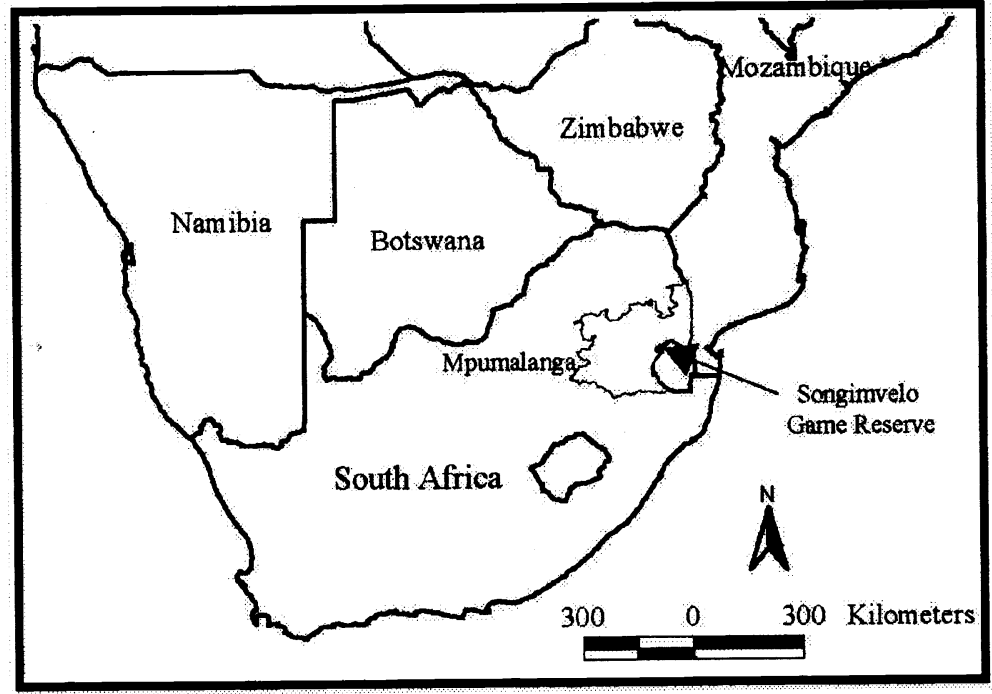

Fig. 1. Locality map of the Songimvelo Game Reserve in southern Africa.

November and March, and varies from less than $800 \mathrm{~mm}$ per year in the southwest to over $1,400 \mathrm{~mm}$ in the north-east (Gamble 1988). Mean minimum monthly temperatures are $5.4^{\circ} \mathrm{C}$ and $8^{\circ} \mathrm{C}$ in July and mean maximum temperatures are $22^{\circ} \mathrm{C}$ and $34^{\circ} \mathrm{C}$ in January for the highland and lowland areas respectively (Stalmans et al. 1999). The generally acid and arenaceous geological substrates in the northeast, combined with a higher rainfall, result in leached acidic soils. In contrast, relatively nutrient-rich soils are found in the Komati Valley.

The SGR is characterised by a long and diverse history of small-scale cropping and livestock in the more fertile lowlands (Van der Merwe and Retief 1995). Since its inception in 1986, 20 species of large herbivores have been re-introduced within the 31,700 ha game-fenced portion of the reserve.

The vegetation of the higher-lying regions of the SGR belongs to the grassland biome. The lower-lying Komati Valley falls within the savanna biome (Rutherford and Westfall 1986). Three of Acocks (1975) vegetation types occur in the SGR. These are veld types 8 (North Eastern Mountain Sourveld) and 63 (Piet Retief Sourveld) which correspond to the North-eastern Mountain Grassland of the grassland biome as defined by Low and Rebelo (1996). Veld type 9 (Lowveld Sour Bushveld) corresponds to the Sour Lowveld Bushveld of the savanna biome. The forest biome is represented in the SGR by numerous isolated patches of for- est, mostly at higher elevation and along drainage lines (Stalmans et al. 1999).

\section{Conceptual approach}

Three basic steps were followed. First, a classification into habitats was produced based on spectral differences in the vegetation. Field data were used to assign classification results into habitats with distinct differences in forage quality. Secondly, the accuracy of the resultant habitat map was assessed using a set of independent field data. Lastly, the ecological relevance of the map produced was evaluated using actual herbivore distribution patterns.

\section{Vegetation field data}

Reference data on the spatial spread of the sour and mixed range were collected for use in developing the wildlife habitat map from remote sensing imagery. A total of 428 sample plots of $30 \times 30 \mathrm{~m}$ were subjectively located across the Songimvelo Game Reserve (SGR) during the period 1993-1995. Cover and height classes for individual woody and grass species within the $30 \times 30$ m plots were estimated using the semi-quantitative measures of the Braun-Blanquet approach (MuellerDombois and Ellenberg 1974) and structural measurements of Edwards (1983). Records of environmental data included elevation (by means of an altimeter $( \pm 20$ $\mathrm{m}$ ) and the 1:50 000 topocadastral maps), geology (according to 1:250 000 geological survey maps (Geological Survey 1986) and locally at a finer scale through personal observations), landscape position (Land 
Type Survey Staff 1989), aspect (whether predominantly N, E, S or W), slope steepness (class estimate), soil texture (using the sausage method (National Working Group for Vegetation Ecology 1986)) and rockiness (estimated as a percentage of the ground cover). The sampling adequately covered the different combinations of environmental factors (Stalmans et al. 1999), in particular elevation and geology which are known to be major determinants of plant community composition and distribution in this montane setting (Deall and Theron 1990). Grazing pressure within each plot was rated according to 3 broad subjective classes: none to light, medium, and heavy.

Ordination and classification of the data set resulted in the delimitation of 18 plant communities identifiable in the field (Stalmans et al. 1999). These 18 communities were combined into 3 main vegetation units: mixed communities, forest and thicket communities, and sour communities. Mixed and sour communities are distinguished using criteria developed by Ellery et al. (1995) regarding the proportion of 'sour' (unpalatable), 'sweet' (palatable) and 'mixed' species. Forest and thicket communities are dominated by woody species with a closed canopy cover.

\section{Manipulation of satellite imagery}

Landsat Thematic Mapper quarter scene WRS 168-3-078, acquired on 8 January 1993, was used. The image was radiometrically corrected. Geometric corrections were applied in both the along-scan and across-scan directions using ground control points. Pixel size is $30 \times 30 \mathrm{~m}$. Bands 3,4 , and 5 were selected. Bands 3 (red) and 4 (near infrared) have been shown to give a good measure of vegetation density, especially as it relates to leaf area, whereas band 5 (middle infrared) provides a good measure of canopy closure (ReyBenayas and Pope 1995). This combination of bands has been used successfully in rangeland (Mackay and Zietsman 1996) and forest studies (Fuller et al. 1998).

A hybrid approach was adopted for the classification of the LANDSAT data. Unsupervised classification allocates each pixel to a certain class based on its spectral characteristics only. In contrast, supervised classification of the imagery requires pre-defined training sites to assign each pixel of the image to a certain class. The drawback to the supervised approach is that it is often difficult to locate and define homogenous training sites for all plant communities of interest. The considerable pixel to pixel variation generally results in many pixels being misclassified (Tueller 1989). Unsupervised classification approaches have worked better in rangelands. The drawback of the unsupervised classification is that subjectivity in the interpretation of the resulting classes is unavoidable.

In this instance, no a priori assumptions were made regarding the information content of the LANDSAT image or of the classification clusters. Instead, the emphasis was on the interpretation of the classification results and the improvement of the classification by incorporating ancillary data (Hutchinson 1982, Medler and Yool 1997). An adequate spatial spread of the ground data was considered key to a successful interpretation of the different classification clusters, in particular where it is known that clusters could be the result of differential spectral response linked to slope and aspect characteristics (Quattrochi and Pelletier 1991). The available sample of 428 vegetation plots adequately covered the different elevation, aspect and geology combinations on the Songimvelo Game Reserve (SGR) (Stalmans et al. 1999) and thus enabled the combination of 2 or more different clusters (based on spectral characteristics) into a single vegetation unit (based on field data).

As a first step, the composite image of the 3 bands was subjected to an unsupervised classification using a histogram peak technique of cluster analysis in the IDRISI Geographical Information System (Eastman 1992). Based on its spectral characteristics, each pixel is assigned to a particular cluster or class. This resulted in 46 classes or clusters, each consisting of multiple individual polygons. Twenty-one clusters each covered less than 100 ha (or $0.2 \%$ of the SGR) scattered across the area. In view of the very small spatial extent of these scattered fragments, these 21 clusters were discarded and the original composite image was again classified with a maximum limit of 25 clusters to ensure that each remaining cluster covered at least 100 ha. In terms of managing the reserve, very small areas cannot realistically be managed differently than the surrounding matrix.

The available field data were used in an objective manner to determine the probability of the classification results representing certain communities. The 428 sample plots were each assigned to one of the 3 vegetation units, namely sour grasslands, mixed grasslands, or forests and thickets. Each point was buffered to cover a window of 3 rows X 3 columns of pixels from the LANDSAT image. This trans- lates into a physical dimension of $90 \times 90$ $\mathrm{m}$ which takes into account inaccuracies inherent to the Global Positioning System (henceforth GPS) positioning (see Fuller et al. 1998 for a similar approach). Habitat type assignments for pixels in the cluster image were compared to that of the buffered sample points. A crosstabulation of the cluster image with the buffered image was made. The resulting matrix was used to assign probabilities for each cluster to represent respectively mixed or sour vegetation based on the percentage mixed and sour sample plots occurring in each cluster. These probabilities were used to produce 2 probability images; one for the mixed and one for the sour vegetation unit. These 2 probability images were combined into a single image by selecting the class image that contains the maximum posterior probability, and assigning that class to the output pixel.

Only 43 of the vegetation plots (10\% of the total sample) represented forests and thickets. Their GPS position was likely to be less accurate because of the thick canopy cover, which when combined with the generally narrow linear distribution of these formations, renders the above approach less meaningful. An alternative approach was therefore followed. Six known and clearly identifiable forest patches were digitized from 1:10,000 scale orthophotos. The classification clusters corresponding best to these patches were identified. All other clusters with the same identity were consolidated across the whole image into a forest/thicket unit. The forest/thicket unit was superimposed on the mixed/sour habitat map.

The habitat map obtained was further refined by assigning any mixed vegetation pixels occurring above $1,300 \mathrm{~m}$ elevation to the sour range. Based on their composition, none of the 112 sample plots situated above $1,300 \mathrm{~m}$ elevation represented mixed vegetation. Secondly, a median $3 \mathrm{X}$ 3 pixel filter was applied to remove random noise and unwanted speckle (Fuller et al. 1998). Lastly, the known extent of the non-native pine (Pinus spp.) plantations occurring within the boundaries of the SGR was superimposed on the map resulting in a final map with 4 habitat units.

\section{Ground-truthing of the satellite- \\ derived map}

Three measurements of error were used to assess the accuracy of the habitat map derived from the satellite imagery. Errors of omission occur when the satellite map fails to recognise the actual habitat class of an independent sample plot. Errors of 
commission result when the satellite map misclassifies the sampling plot from the independent data set. A Kappa Index of Agreement (KIA), both for all classes and on a per category basis, constitutes the third measure of error. The KIA ranges from 0.0 indicating no correlation to 1.0 indicating perfect correlation (Eastman 1992).

A data set collected during 1989 prior to, and independently from the present study was used to assess the accuracy of the habitat map. Grasslayer composition of 85 plots of $25 \times 100 \mathrm{~m}$, subjectively located across the Songimvelo Game Reserve (SGR), was assessed by means of 100 points per plot using the nearest-rooted plant criterion (Mentis 1984). These plots were assigned to the mixed and sour vegetation units based on species composition. A crosstabulation was performed between the assigned plots and the satellite-derived image. Habitat categories from the plots were compared with those of the satellite map. A tabulation was kept of the number of cells in each category combination. No tabulations were made for cells marked with a 0 on the groundtruth map. Ommission, commission and KIA were calculated from the crosstabulation results.

\section{Ecological significance of the satel- lite-derived map}

Overall stocking densities for the Songimvelo Game Reserve (SGR) (1815 $\mathrm{kg} \mathrm{km}^{-2}$ during 1994 and $3288 \mathrm{~kg} \mathrm{~km}^{-2}$ during 1999) fall well below the estimated grazing capacity for this part of the country $\left(5,000 \mathrm{~kg} \mathrm{~km}^{-2}\right.$ or higher)(Barnes 1990). Given these overall low stocking densities on the reserve and large contiguous areas of different habitats being available to game, the spatial distribution of large herbivores should reflect the spatial distribution of mixed and sour grasslands. This would particularly apply during winter when forage resources are most limiting both in terms of quality and quantity (Voeten and Prins 1999).

Two helicopter game counts were conducted during the winter months of August 1994 and September 1999 respectively as herbivores were more easily visible due to the lower leaf cover (as the vast majority of savanna trees are deciduous). Counts were conducted by means of a Bell Jetranger helicopter seating a pilot, navigator and 2 observers in the back recording game within $300 \mathrm{~m}$ wide parallel strips. The helicopter was maintained at a constant height of $53 \mathrm{~m}$ above the ground. Airspeed was maintained at around $96 \mathrm{~km}$ hour $^{-1}$ (60 knots). Each count was conduct- ed within a period of 3 days. Extensive field experience from the pilot and observers indicates that no large-scale movement of game occurs within such a limited time period. Breaks during the counting were made along natural boundaries across which little or no short-term movement of game is expected. Doublecounting of individual animals or herds is avoided by herding animals from the counting strip deeper into strips already counted. A GPS co-ordinate was recorded for each game sighting. Viljoen and Retief (1994) found the measured errors between actual and recorded localities using GPS technology for game counts to be well within the requirements for ecological work of this kind. Each GPS point was compared with the habitat map to establish whether the sighting fell within mixed or sour range. A value in $\mathrm{kg} \mathrm{km}^{-2}$ was calculated for each point based on the species and number of animals involved in each sighting.

The underlying assumption in distinguishing between mixed and sour habitats is that nutritional value represents the overriding factor determining herbivore distribution. Three other important factors however could influence herbivore distribution across the landscape. These are water availability, feed availability and fire history. Another complicating factor in the SGR is the presence of a number of human settlements within the game-fenced area. It is critical to ascertain that the assessment of the value of the mixed and sour habitats delimited on the satellite map is not biased through 1 of these factors.

Distance to the nearest watering point is known to be important in determining herbivore use intensity (Thrash et al. 1995). With the GIS a distance analysis was performed from all known perennial streams and rivers in order to establish whether any parts of the SGR might be unavailable to water-dependent species such as impala (Aepyceros melampus Lichtenstein) (Young 1970).

A crude index of grass quantity available in the sour and mixed habitats was calculated as follows during the survey of the 428 vegetation plots. The class value for the grass cover estimate $(1=$ sparse, 2 $=$ open, or 3 = closed)(structural terminology and categories follow Edwards (1983)) in each sample plot was multiplied by the square root of the midpoint of the 3 following height classes $(1=<0.5 \mathrm{~m}, 2=$ 0.5 to $1.0 \mathrm{~m}, 3=1.0$ to $2.0 \mathrm{~m}$ ). Trollope and Potgieter (1986) used a similar approach to measuring standing phytomass.
Many African ungulates are attracted to recently burnt grassland (Wilsey 1996). The extent of areas burnt during the 12 months preceding the 1994 and 1999 winter helicopter counts was determined for the mixed and sour habitats. Fires have been mapped since 1987 in the Songimvelo Game Reserve (SGR) and the data have been consolidated in the GIS. A crosstabulation of burnt and unburnt areas was performed with the GPS positions of the game to assess relative and absolute stocking densities.

Illegal hunting and snaring are not considered to have a major effect around the settlements within the SGR. However, competition from livestock, habitat modification through cultivation and exclusion through protective fencing around croplands could negatively influence wild herbivores. A distance analysis was performed from the GPS positions of the settlements. An overlay of the buffered image was made with the habitat map. The resulting distance-habitat map was crosstabulated with the GPS positions of the game.

Throughout the assessment of the ecological significance of the satellite-derived map, a Chi-square goodness-of-fit analysis (Zar 1984) was used to evaluate differences between the observed crosstabulation results and the expected patterns of occurrence based on proportional habitat availability.

\section{Results and Discussion}

\section{Habitat units}

Twenty-five out of the 428 sample plots represented wetland and non-native communities dominated by planted pine or closed-canopy stands of self-seeded Black wattle (Acacia mearnsii De Wild.) and were not considered further. Of the remainder, 43 plots represented forests or thickets. No single plot was classified as sweet range requiring more than $30 \%$ of the total cover to consist of 'sweet' species and less than $20 \%$ cover by 'sour' species (Ellery et al. 1995). A total of 224 plots were classified as sour range with 'sour' species contributing more than $60 \%$ of the cover of the plot and 'sweet' species contributing less than $20 \%$ cover. The remaining 136 plots were by definition mixed range by not conforming to either the sweet or sour criteria. The grazing intensities recorded in the field indicate a dramatic and significant difference in usage of the mixed and sour vegetation units $\left(\chi^{2}=\right.$ $\left.101.64, \chi^{2} 0.05,1=3.481, \mathrm{P}<0.001\right)$. 


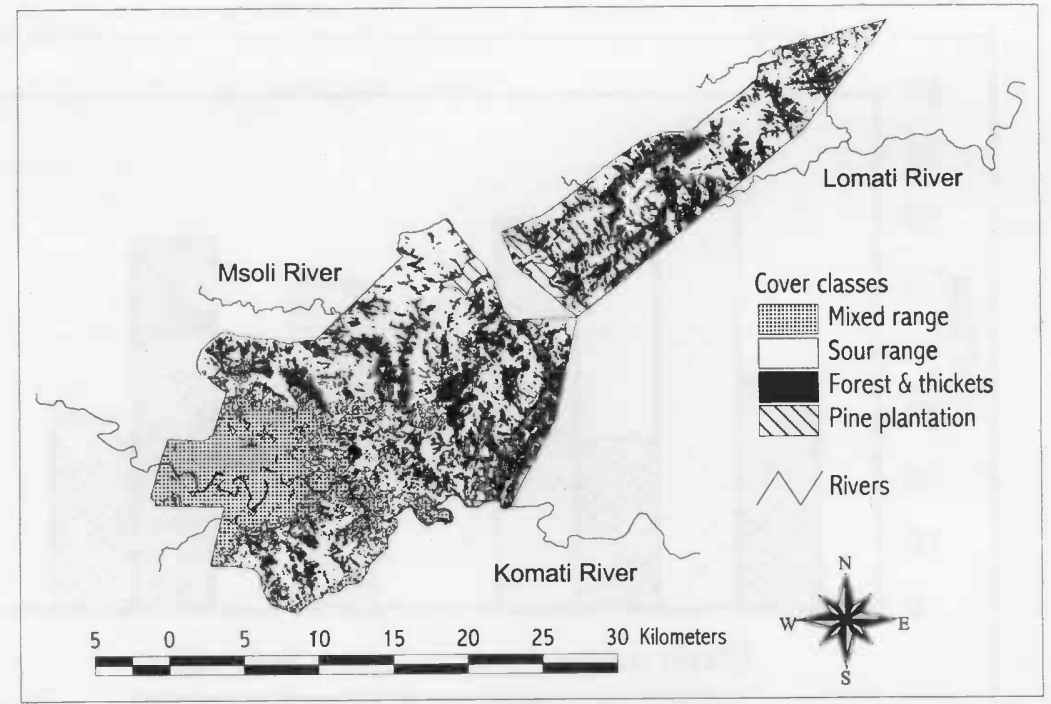

Fig. 2. Satellite-derived range map of the Songimvelo Game Reserve. Note mixed range in the south-western lower-lying Komati River valley and sour range in the north-eastern high mountains.

Whereas $57.3 \%$ of the mixed plots were assessed as being medium to heavily grazed, only $7.6 \%$ of the sour plots were similarly rated. This indicates that the split into sour and mixed range based on floristic composition criteria translates into an ecologically meaningful difference to herbivores.

\section{Habitat map}

Crosstabulation of the 25 classification clusters with the vegetation plots generally resulted in a high individual probability for each of the clusters to represent either sour or mixed range. More than half of the surface area of the Songimvelo Game Reserve (SGR) has a cluster probability above $80 \%$. For $92.2 \%$ of the total area, the cluster probability is above $65 \%$. Only 2 clusters have less than a $65 \%$ probability factor of representing only sour or only mixed vegetation. These 2 clusters only make up $7.8 \%$ of the total area. Their spatial distribution is of interest. The 2 clusters are spread in a horseshoe marking the transition from the low-lying Komati Valley to the higher mountains to the north and east (Fig. 2). The Themeda triandra Forssk. (Rooigras)- Cymbopogon spp. short Grassland community which is a transitional community intermediate between typical mixed woodland communities and sour grassland communities was identified for this zone (Stalmans et al. 1999). The low probability scores for these clusters probably reflect the heterogeneous and intermediate nature of the vegetation in this particular area.

The final habitat map clearly depicts the mainly mixed vegetation in the low-lying Komati Valley and Msoli Valley (Fig. 2). The higher-lying mountains to the north and east are mainly covered by sour vegetation. The forest and thickets also occur mostly at higher elevation as small pockets and linear formations in drainage lines. Pine plantations are located in the northeast. The mixed vegetation is the smallest of the 3 main units covering 8,504 ha or $17.3 \%$ of the SGR, followed by the thickets and forests $(10,119$ ha or $20.6 \%)$. The sour habitat occupies 29,684 ha which represent $60.4 \%$ of the game reserve.

\section{Ground-truthing of satellite-derived map}

The habitat map conforms in broad terms to the understanding of the vegetation as obtained through ordination and classification of the 428 sample plots (Stalmans et al. 1999). Mixed communities occur mostly in the Komati Valley and sour communities at higher elevation.

The independent sample of 85 plots used for the validation consisted of 52 mixed and 33 sour plots. The unsupervised

Table 1 Error matrix resulting from the crosstabulation of the 85 independent sample plots with the habitat map of the Songimvelo Game Reserve obtained through unsupervised classification of LANDSAT Thematic Mapper quarter scene WRS 168-3-078.

\begin{tabular}{lcccc}
\hline \hline & \multicolumn{4}{c}{ Satellite-derived habitat map } \\
\cline { 2 - 5 } Independent data set & $\begin{array}{c}\text { Mixed } \\
\text { range }\end{array}$ & $\begin{array}{c}\text { Sour } \\
\text { range }\end{array}$ & Row total & $\begin{array}{c}\text { Commission error } \\
(\%)\end{array}$ \\
\hline Mixed range & 40 & 12 & 52 & 23.1 \\
Sour range & 5 & 28 & 33 & 15.2 \\
Column total & 45 & 40 & 85 & \\
Omission error $(\%)$ & 11.1 & 30.0 & & \\
\hline
\end{tabular}
recorded for the 1994 count and 865 for procedure correctly classified $76.9 \%$ of the mixed and $84.8 \%$ of the sour sample plots. The Kappa coefficient (KIA) was 0.59 . The overall percentage correct classification was $80 \%$ (obtained by dividing the sum of the diagonal entries in the error matrix by the total number of sample plots) (Table 1).

A good correspondence between the 6 digitized forest patches and the satellitederived forest patches was obtained. The overall correct classification for the 6 patches was $78.4 \%$. The KIA was 0.74 . The satellite map overestimated the actual forest cover by $13.6 \%$. The forest/thicket coverage was simply used to identify those parts of the SGR not dominated by grasslands which were the focus of the present study.

Classification accuracy reported by other researchers mapping landcover (Brondizio et al. 1996, Fuller et al. 1998, Hodgson et al. 1988, Lunetta and Balogh 1999), forest cover (Congalton et al. 1993) and grassland cover (Lauver and Whistler 1993) ranged from 69 to $94 \%$. The accuracy figures of 78 to $80 \%$ achieved for the mixed/sour vegetation and forest patches on the SGR are thus considered to be satisfactory for an operational product of this kind.

\section{Ecological significance of the habi- tat map}

During 1994 a total of 22,800 ha was covered by the helicopter survey whereas during 1999 the whole game-fenced area of 31,700 ha was flown. A total of 705 GPS coordinates of wild herbivores were the 1999 count. The associated animal biomass per GPS locality ranges from $10 \mathrm{~kg}$ (1 klipspringer (Oreotragus oreotragus Zimmermann)) to $16,560 \mathrm{~kg}$ (a herd of 36 eland (Taurotragus oryx Pallas)). Elephant (Loxodonta africana Blumenbach) constituted $11.4 \%$ of the total metabolic mass of wild herbivores present on the Songimvelo Game Reserve (SGR) in 1999. They generally move around in 1 or 2 herds and large daily movements across the land- 
scape have been observed in the field. Elephant were not considered further for this study as a single GPS observation could dramatically bias the evaluation of habitat selection.

The results from the crosstabulation clearly indicate the proportionally greater selection of the mixed compared to the sour vegetation (Fig. 3). Although only representing $31.0 \%$ (range 26.4 to $35.7 \%$ ) of the available habitat, the mixed vegetation holds $66.1 \%$ (range 60.4 to $71.9 \%$ ) of the game. In contrast, $54 \%$ (range 50.4 to $57.7 \%$ ) of the surveyed area consisted of sour vegetation that held only $26.5 \%$ (range 22.9 to $30.1 \%$ ) of the game. This differential pattern in stocking rate according to range type remained similar for the 1994 and 1999 surveys. The forests and thickets represented $14.9 \%$ (range 13.9 to $15.8 \%$ ) of the available habitat but contributed only $7.3 \%$ (range 5.2 to $9.5 \%$ ) to the game stocking. The possibility exists that game numbers were undercounted for forests and thickets because of the difficulty of observing animals under the canopy. Field observations however suggest that few herbivores are found in this vegetation formation and particularly not in the dense and moist forests.

In terms of absolute values, the mixed portion of the landscape had an average stocking density 4 times higher than the sour portion (Table 2). This difference reflects the general stocking densities of $10^{3}$ to $10^{4} \mathrm{~kg} \mathrm{~km}^{-2}$ for medium and high

Table 2 Stocking densities during winter in the different habitats of the Songimvelo Game Reserve.

\begin{tabular}{lccc}
\hline \hline & \multicolumn{3}{c}{ Stocking density } \\
\cline { 2 - 4 } Habitat & 1994 & 1999 & $\begin{array}{c}\text { Weighted } \\
\text { mean }\end{array}$ \\
\hline & & & -198 \\
Mixed & 3415 & 2989 & 319 \\
Sour & 771 & 684 & 717 \\
Forest/thicket & 629 & 784 & 724 \\
Weighted mean & 1694 & 1309 & 1470 \\
\hline 'weighted to take into account different extent of habitat \\
and differences in area surveyed during 1994 and 1999 \\
respectively.
\end{tabular}

soil nutrient status dystrophic savannas with a rainfall of approximately $1,000 \mathrm{~mm}$ as compared to only $10^{2}$ to $10^{3} \mathrm{~kg} \mathrm{~km}^{-2}$ for low soil nutrient status savannas reported by East (1984). As mentioned in the description of the SGR, the lower-lying Komati Valley receives a much lower rainfall and is characterised by more fertile substrates compared to the higher-

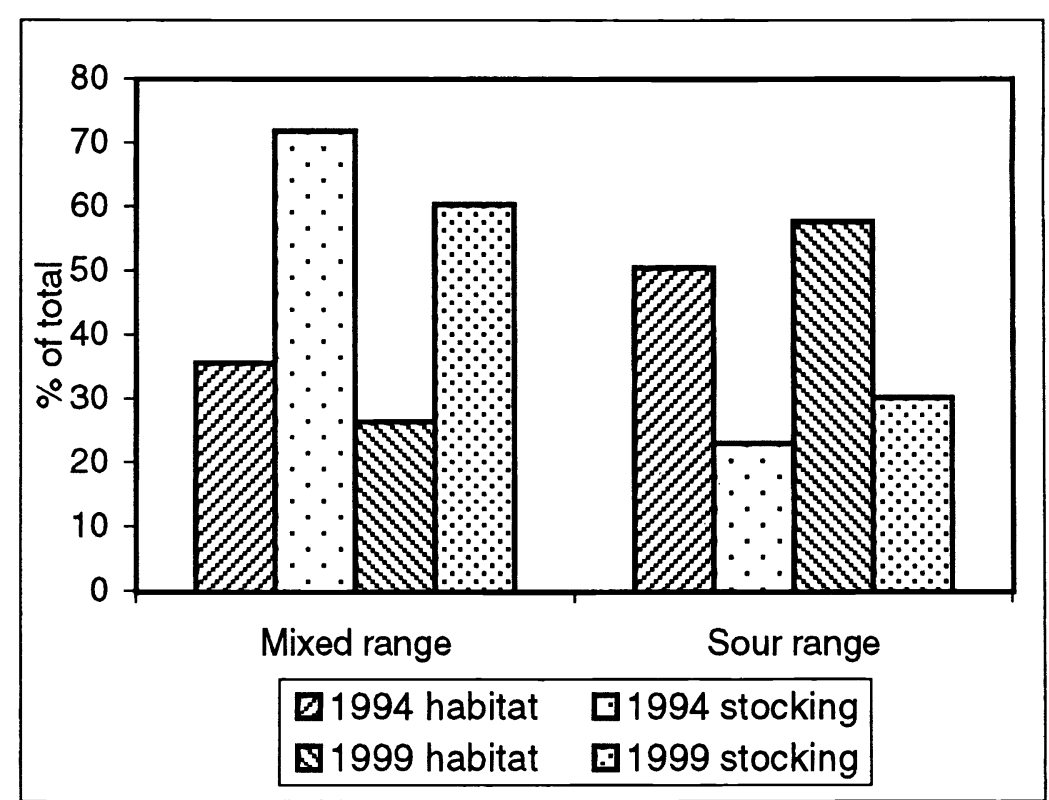

Fig. 3. Mean relative habitat availability and stocking densities in the Songimvelo Game Reserve for the 1994 and 1999 game counts. Note the proportionally greater stocking of the mixed range.

lying north-easterly parts.

Differences in stocking rates between 1994 and 1999 cannot be directly compared. They are more a consequence of the differences in flight areas covered than a biologically significant change in animal numbers. The total recorded wild herbivore biomass, excluding elephant, was $391,367 \mathrm{~kg}$ in 1994 and $412,471 \mathrm{~kg}$ in 1999. The 1999 figure is $5.4 \%$ higher but is spread across an area $30 \%$ larger than 1994 resulting in an apparent drop of 23\% in stocking rates (Table 2). During the intervening years, game numbers were controlled and a total of $272,478 \mathrm{~kg}$ was removed, mostly through live capture and relocation to other conservation areas. The higher total biomass figure recorded during 1999 therefore reflects the larger area surveyed and not an increase in wildlife numbers.

The overall stocking rate for the Songimvelo Game Reserve (SGR) is low compared to the agricultural guidelines for this part of the country (Barnes 1990). In view of the overall conservative stocking rates one can assume a fair degree of choice being available to the herbivores regarding area selection. The other factors that could influence herbivore distribution are the availability of water, availability of forage, fire history and human disturbance. No artificial waterpoints are provided in the SGR. The perennial Komati River bisects the game-fenced area.
Numerous other perennial rivers and streams occur. Fully $98.9 \%$ of the SGR is located within $2 \mathrm{~km}$ from perennial water. No part is situated further than $3 \mathrm{~km}$ from perennial water. The average radius of range utilisation around watering points in winter in the Kruger National Park has been documented as respectively $3.5 \mathrm{~km}$ for impala, $11.25 \mathrm{~km}$ for zebra (Equus burchellii Gray) and $11.5 \mathrm{~km}$ for blue wildebeest (Connochaetus taurinus Burchell)(Young 1970). Water is therefore not considered a major constraint to, or determinant of herbivore distribution in the SGR.

The crude index of grass quantity based on the 3 cover and 3 height classes has a possible range from 1 to 5.2. Based on the actual recorded values a mean of 2.9 (SD 1.02) was obtained for the mixed habitat ( $\mathrm{n}=136$ sample plots) and 3.3 (SD 0.83) for the sour habitat ( $n=224$ plots). A larger quantity of grass is thus generally available in the sour habitat. This difference is however not significant $\left(\chi^{2}=0.03, \chi_{0.05,1}^{2}\right.$ $=3.481,0.75<\mathrm{P}<0.90)$. The greater standard deviation for the mixed range reflects the figure of $57.3 \%$ of the plots assessed as being medium to heavily grazed, compared to only $7.6 \%$ of the sour plots being grazed. The mixed range consists of shortly grazed areas as well as little grazed areas, whereas the sour range is generally uniformly non-utilised. In the field, the availability of grass, particularly in winter, is clearly more limited on the mixed areas. 
Table 3. Stocking densities during winter in the different habitats of the Songimvelo Game Reserve in relation to fire history and distance from human settlements.

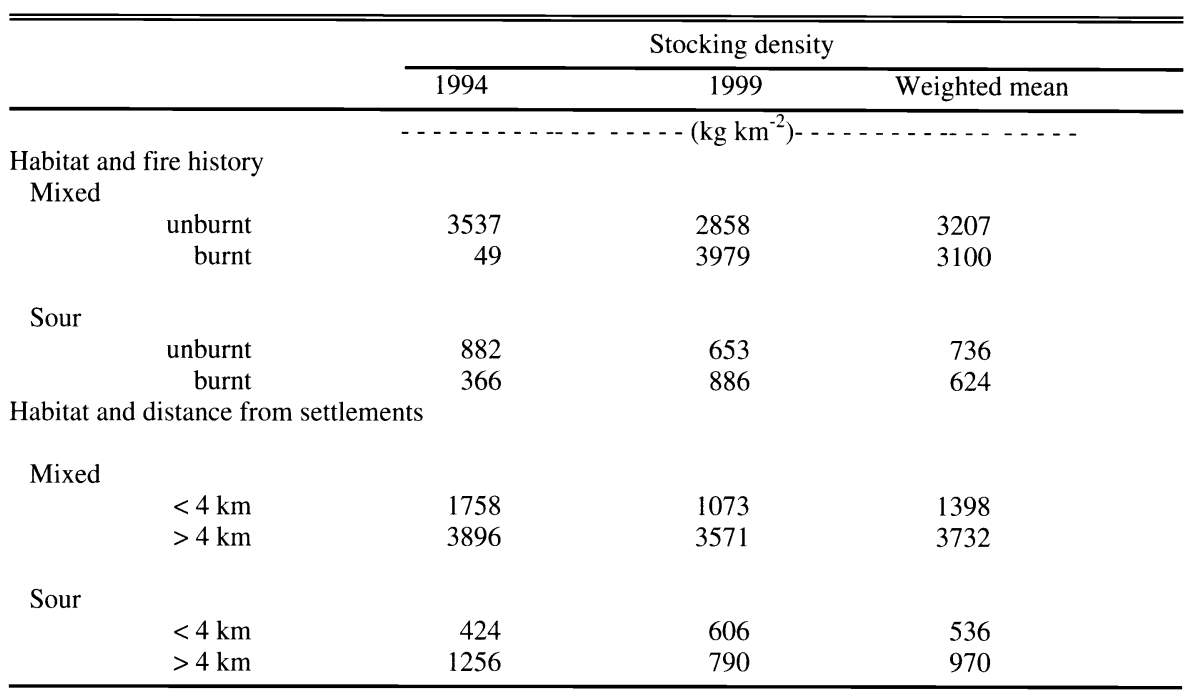

Taking into account the lower stocking densities on the sour habitat, herbivore distribution is clearly not primarily governed by the absolute quantitative availability of feed.

The difference in order of magnitude of stocking density was maintained for mixed and sour habitats regardless of burning history (Table 3 ). Overall, mixed range in the SGR is stocked at a rate 4 to 5 times higher than sour range whether burnt or unburnt. This difference is significant $\left(\chi^{2}\right.$ $\left.=18120.6, \chi_{0.05,1}^{2}=3.481, \mathrm{P}<0.001\right)$. Differences were observed between individual years. The burnt areas were stocked at a lower density during 1994 within each habitat. The inverse pattern, with higher stocking densities on burnt areas, was observed during 1999. Objective evaluation of this pattern was complicated by the relatively small extent of the burnt areas. The burnt portion covered only 279 ha $(3.4 \%)$ of the total mixed habitat surveyed in 1994 and only 970 ha $(11.7 \%)$ of the mixed habitat in 1999. Burnt areas covered 2451 ha $(21.6 \%)$ and 2407 ha $(13.4 \%)$ of the sour habitat respectively in 1994 and 1999. Chance events and daily movements of herbivores could be an important factor in the evaluation of the relatively small burnt areas. Field observations (Unpublished data, M.E. Stalmans) certainly indicate a greater use of burnt areas at a smaller spatial scale and for a limited period of time. In summary, at a large spatial scale and a temporal scale of one year, the fundamental difference in the nature of the mixed and sour habitat overrides fire history.

Some 30 human settlements occur mostly in the southern and eastern boundary areas of the game-fenced portion of the single and sometimes extended family which practices subsistence agriculture and receives remittances from family Songimvelo Game Reserve (SGR). Mean herd size in 1992 was 27 head of cattle (range 0 to 126) (Heinsohn et al. 1992). Cultivation mainly consists of maize. Mean area of lands cultivated by a single Trees and branches are cut down for building purposes and as firewood. The maximum distance in the SGR away from settlements is between 12 and $13 \mathrm{~km}$. A cutoff value of $4 \mathrm{~km}$ was used for the habitat evaluation as $48.5 \%$ of the SGR is less than $4 \mathrm{~km}$ from a settlement leaving $51.5 \%$ of the area to be further than $4 \mathrm{~km}$ away.

The stocking density of wild ungulates on areas less than $4 \mathrm{~km}$ away from settlether away for both mixed and sour habitat for both counts (Table 3 ). This apparent negative effect from human settlements on game stocking density tested significant $\left(\chi^{2}\right.$ $\left.=1653.9, \chi^{2} 0.05,1=3.481, \mathrm{P}<0.001\right)$. Nevertheless, mixed areas close to settlements are still stocked at values two to three times higher than equivalent sour areas. Furthermore, the stocking density on mixed areas close to settlements still remains higher than the stocking density on sour areas further away from settlements.

Human settlements have been documented as having a negative impact on wild herbivore densities for a distance of at least $7 \mathrm{~km}$ in a forest environment (Eltringham 1990) and $10 \mathrm{~km}$ in arid enviSGR. Each settlement is occupied by a members employed outside the family was 2.9 ha (range 0.4 to 9 ha). ments was less than half that of areas fur- ronments (Verlinden 1997). The definite negative impact within the $4 \mathrm{~km}$ cut-off selected for the SGR is therefore not unexpected but it does not override the fundamental difference in habitat quality between mixed and sour range.

At the landscape scale and at temporal scales of a year or more, the broad differences in habitat quality and its spatial distribution clearly outweigh the effects of any short-term, localised management action or human disturbance. Senft et al. (1987) hypothesised that in the absence of overriding constraints, foraging behaviour by large herbivores should produce a landscape stocking rate that is a linear function of landscape productivity. The mixed range, although limited in extent, is critical to wild herbivores in the SGR.

The habitat make-up of the SGR as derived from remote sensing and as confirmed by ground data, forms the base upon which further studies can be undertaken regarding individual herbivore species preference, performance and stocking.

\section{Conclusions}

The broad habitat map, which was derived from the satellite imagery, identified mixed and sour range units differing in terms of composition and palatability. Broad herbivore distribution patterns were well correlated with the spatial distribution of these habitat units derived from remote sensing. At the landscape scale, the habitat quality in terms of grass layer composition and palatability overrides its quantitative availability and its smaller-scale fire history. Because of its ubiquitous nature, water distribution is not a significant factor in the Songimvelo Game Reserve (SGR). Although stocking densities of wild ungulates are lower close to human settlements, the overall high ratio in stocking densities between mixed and sour habitat is maintained. These findings, applying to both the 1994 and 1999 game surveys, suggest the fundamental differences in forage quality between range types persist across seasons. Anecdotal field evidence from intervening years supports this assumption.

The integration of field data and satellite imagery into a GIS system for analysis offers a powerful tool for the objective quantification and mapping of the spatial distribution of available habitat. The resulting image is ecologically relevant and of practical value to the manager and ecologist dealing with this heterogeneous system. As such this approach could be 
applied to other nature reserves and to the growing number of game farms in southern Africa and elsewhere.

\section{Literature Cited}

Acocks, J.P.H. 1975. Veld types of South Africa. Mem. Bot. Surv. So. Afr. 40:1-128.

Barnes, D.L. 1990. A survey of grazed and ungrazed grasslands in the south-eastern Transvaal highveld. 1. Palatability composition and grazing capacity. J. Grassl. Soc. So. Afr. 7:217-222.

Barnes, K.N. (ed.). 1998. The important bird areas of southern Africa. Avian Demography Unit, BirdLife South Africa, Johannesburg, So. Afr.

Brondizio, E., E. Moran, P. Mausel, and Y. Wu. 1996. Land cover in the Amazon estuary: Linking of the thematic mapper with botanical and historical data. Photogramm. Eng. Remote Sens. 62:921-929.

Congalton, R.G., K. Green, and J. Teply. 1993. Mapping old growth forests on National Forests and Park Lands in the Pacific Northwest from remotely sensed data. Photogramm. Eng. Remote Sens. 59:529-535.

Deall, G.B. and G.K. Theron. 1990 . Ordinations as a tool for substantiating and interpreting floristic classifications: A case study. Bothalia 20:223-227.

East, R. 1984. Rainfall, soil nutrient status and biomass of large African savanna mammals. Afr. J. Ecol. 22:245-270.

Eastman, J.R. 1992. IDRISI. Clark University Graduate School of Geography. Worcester, Mass.

Edwards, D. 1983. A broad-scale structural classification of vegetation for practical purposes. Bothalia 14: 705-712.

Ellery, W.N., R.J. Scholes, and M.C. Scholes. 1995. The distribution of sweetveld and sourveld in South Africa's grassland biome in relation to environmental factors. Afr. J. Range For. Sci. 12:38-45.

Eltringham, S.K. 1990. Wildlife carrying capacities in relation to human settlement. Koedoe 33:87-97.

Fairbanks, D.H.K. and M.W. Thompson. 1996. Assessing land-cover map accuracy for the South African Land-Cover database. So. Afr. J. Sci. 92:465-470.

Fuller, R.M., G.B. Groom, S. Mugisha, P. Ipulet, D. Pomeroy, A. Katende, R. Bailey, and R. Ogutu-Ohwayo. 1998. The integration of field survey and remote sensing for biodiversity assessment: a case study in the tropical forests and wetlands of Sango Bay, Uganda. Biol. Conserv. 86:379-391.

Gamble, F. 1988. Climate of the Transvaal Escarpment, p. 1-4. In: A.A. Ferrar, G. Isaacs and J.R. Stacey (eds.), Environmental conservation features of the Transvaal Escarpment. Occasional Rep. 31. CSIR, Pretoria.
Geological Survey. 1986. Geology map 1:250,000 geological series: 2430 Barberton. Government Printer, Pretoria.

Heinsohn, R-D., S.J. Woodburne, and S.E. Alexander. 1992. Demographic, socio-economic and attitudinal surveys of affected communities in and around Songimvelo Game Reserve. A.C.E.R. (Africa) Tech. Rep. to Dept. Development Aid, Pretoria.

Hodgson, M.E., J.R. Jensen, H.E. Mackey, and M.C. Coulter. 1988. Monitoring wood stork foraging habitat using remote sensing and geographic information systems. Photogramm. Eng. Remote Sens. 54:1601-1607.

Hutchinson, C.F. 1982. Techniques for combining Landsat and ancillary data for digital classification improvement. Photogramm. Eng. \& Remote Sens. 48:123-130.

Land Type Survey Staff. 1989. Land types of the map 2530 Barberton. Memoirs of the Agric. Natur. Resources of So. Afr. 13, Pretoria.

Lauver, C.L. and J.L. Whistler. 1993. A hierarchical classification of Landsat TM imagery to identify natural grassland areas and rare species habitat. Photogramm. Eng. Remote Sens. 59:627-634.

Low, A.B. and A.G. Rebelo. (eds.) 1996. Vegetation of South Africa, Lesotho and Swaziland. Dept. Environ. Affairs and Tourism, Pretoria.

Lunetta, R.S. and M.E. Balogh. 1999. Application of multi-temporal Landsat $5 \mathrm{TM}$ imagery for wetland identification. Photogramm. Eng. Remote Sens. 65:1303-1310

Mackay, C.H. and H.L. Zietsman. 1996. Assessing and monitoring rangeland condition in extensive pastoral regions using satellite remote sensing and GIS techniques: An application to the Ceres Karoo region of South Africa. Afr. J. Range For. Sci. 13:100--112.

Medler, M.J. and S.R. Yool. 1997. Improving thematic mapper based classification of wildfire induced vegetation mortality. Geocarto Int. 12:49-58.

Mentis, M.T. 1984. Monitoring in South African grasslands. South African Nat. Sci. Programmes Rep. 91, CSIR, Pretoria.

Mueller-Dombois, D. and H. Ellenberg. 1974. Aims and methods of vegetation ecology. John Wiley \& Sons, New York.

National working group for vegetation ecology. 1986. Soil classification according to the binomial classification system. Tech. Commun. 3, Pretoria.

Quattrochi, D.A. and R.E. Pelletier. 1991. Remote sensing for analysis of landscapes: An introduction. p. 52-76. In: M.G. Turner and R.H. Gardner (eds.), Quantitative methods in landscape ecology. Springer-Verlag, New York.

Rey-Benayas, J.M. and K.O. Pope. 1995. Landscape ecology and diversity patterns in the seasonal tropics from Landsat TM imagery. Ecol. Appl. 5: 386-394.
Rutherford, M.C., and R.H. Westfall. 1986. Biomes of southern Africa - An objective categorisation. Mem. Bot. Surv. So. Afr. 54:1-98.

Senft, R.L., M.B. Coughenour, D.W. Bailey, L.R. Rittenhouse, O.E. Sala, and D.M. Swift. 1987. Large herbivore foraging and ecological hierarchies. BioSci. 37:789-799.

Stalmans, M., E.R. Robinson, and K. Balkwill. 1999. Ordination and classification of vegetation of Songimvelo Game Reserve in the Barberton Mountainland, South Africa as a basis for the assessment of wildlife habitat distribution and quality. Bothalia 29:305-325.

Thrash, I., G.K. Theron, and J. du P. Bothma. 1995. Dry season herbivore densities around drinking troughs in the Kruger National Park. J. Arid Environ. 29:213-219.

Trollope, W.S.W. and A.L.F. Potgieter. 1986. Estimating grass fuel loads with a disc pasture meter in the Kruger National Park. J. Grassl. Soc. So. Afr. 3:148-152.

Trollope, W.S.W., L.A. Trollope, and O.J.H. Bosch. 1990. Veld and pasture management terminology in southern Africa. J. Grassl. Soc. So. Afr. 7:52-61

Tueller, P.T. 1989. Remote sensing technology for rangeland management applications. J. Range Manage. 42:442-453.

Van der Merwe, P.D.R. and E.F. Retief. 1995. The Songimvelo Game Reserve inhabitants: individual data and background information. Tech. Rep. Dept. of Constitutional Development, Pretoria, So. Afr.

Verlinden, A. 1997. Human settlements and wildlife distribution in the southern Kalahari of Botswana. Biol. Conserv. 82:129-136.

Viljoen, P.C. and P.F. Retief. 1994. The use of the Global Positioning System for realtime data collecting during aerial surveys in the Kruger National Park. Koedoe 37:149-154.

Voeten, M.M. and H.H.T. Prins. 1999. Resource partitioning between sympatric wild and domestic herbivores in the Tarangire region of Tanzania. Oecologia 120:287-294.

Wilkinson, G.G. 1996. A review of current issues in the integration of GIS and remote sensing. Int. J. Geographical Information Systems 10:85-101.

Wilsey, B.J. 1996. Variation in use of green flushes following burns among African ungulate species: the importance of body size. Afr. J. Ecol. 34:32-38.

Young, E. 1970. Water as faktor in die ekologie van wild in die Nasionale Krugerwildtuin. Ph.D. Thesis, Univ. Pretoria, So. Afr.

Zar, J.H. 1984. Biostatistical analysis. Prentice-Hall, N.J. 